\title{
The Broad Street pump revisited: dairy farms and an ongoing outbreak of inflammatory bowel disease in Forest, Virginia
}

\author{
Ellen S Pierce ${ }^{1}$, Stephen M Borowitz ${ }^{2^{*}}$ and Saleh A Naser ${ }^{3}$
}

\begin{abstract}
We report an ongoing outbreak of ulcerative colitis and Crohn's disease in Forest, Virginia involving 15 unrelated children and teenagers who resided in close proximity to dairy farms. Some of our cases demonstrated serologic evidence of Mycobacterium avium subspecies paratuberculosis infection, suggesting its potential role as an etiologic agent.
\end{abstract}

Keywords: inflammatory bowel disease, paratuberculosis, cluster, outbreak, aerosolization, fecal-oral waterborne transmission

\section{Findings}

On December 4, 1854, at a meeting of the London Epidemiological Society, Dr. John Snow presented a map illustrating multiple cases of cholera deaths earlier that year in an area of London near a now famous pump on Broad Street (Figure 1) [1]. The word "outbreak" was used to describe the deaths from cholera occurring within houses that obtained water from the Broad Street pump, and the map of the cases' houses in relationship to the pump helped establish that an infectious microorganism in the pump's water was the cause of the cases' cholera.

Multiple cases of Crohn's disease occurring within a geographic area have been referred to as clusters rather than outbreaks, but some investigators of these clusters have concluded that some cases of Crohn's disease, like cholera, are caused by an infectious microorganism [2]; a microorganism present in unpasteurized milk [3] and cheese [4], and in animal feces that contaminate well $[4,5]$ and river water $[6,7]$ and lakes and ponds used for swimming and other recreational purposes [7].

Mycobacterium avium subspecies paratuberculosis (MAP), the cause of a chronic diarrheal disease in dairy cattle called Johne's ('Yo-knee's') disease, is present in an infected dairy cow's feces and milk [8], and could

\footnotetext{
* Correspondence: Witz@virginia.edu

${ }^{2}$ Division of Pediatric Gastroenterology, Hepatology and Nutrition, University of Virginia Children's Hospital, Box 800386 HSC, Charlottesville, Virginia 22908 USA
}

Full list of author information is available at the end of the article play an etiologic role in Crohn's clusters. Some investigators have proposed that MAP may cause some cases of Crohn's disease $[2,8]$ and the other major form of inflammatory bowel disease ulcerative colitis [9].

While the existing medical literature suggests MAP is transmitted to humans through milk and milk products, it seems more likely that most people are exposed to the organism through water contaminated with bovine fecal matter. The symptoms of ulcerative colitis and Crohn's disease are similar to many enteric infections, and most enteric infections are transmitted via the fecal-oral route.

Adult male dairy farm workers have more than an eightfold increased risk of developing ulcerative colitis [10]; however the following is the first published cluster of inflammatory bowel disease where the affected individuals lived near dairy farms and where anti-MAP IgG antibodies were detected in a number of the patients' sera.

Our eleven children with Crohn's disease and four children with ulcerative colitis were either born in Forest or moved there before any of them developed any symptoms of inflammatory bowel disease. They ranged in age from 5 to $181 / 2$ years at the onset of their symptoms and their mean age at diagnosis was 12.4 years. The first case was diagnosed in 1994 and the most recent case was diagnosed in January 2011.

Figure 2 is a map of Forest showing the locations of seven of our 15 cases' homes. Two homes are immediately 


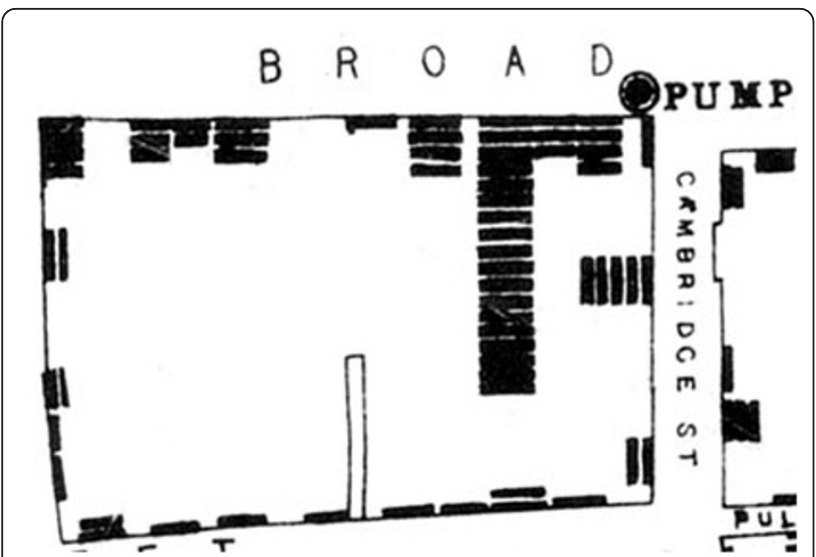

Figure 1 Map of the 1854 London cholera outbreak. The pump is indicated by a circle in the upper right hand corner of the figure. Deaths from cholera in each household are indicated by bars. Reprinted with the very kind permission of Dr. Ralph Frerichs from his John Snow website, http://www.ph.ucla.edu/epi/snow/ mapsbroadstreet.html.

adjacent to dairy farms and the others are close to Ivy Lake, Otter River, Elk Creek or Ivy Creek or their tributaries, all of which receive rain water runoff from four of the six farms currently located in Forest.

Blinded serum samples collected from seven of our children with Crohn's disease and two of our children with ulcerative colitis were tested for anti-MAP antibodies using p35 and p36 MAP-specific antigens. This enzyme linked immunosorbent assay is a quantitative measurement of MAP exposure [11]. Five of the seven samples from children with Crohn's disease were strongly positive for MAP antibodies.

The terms "cluster" and "outbreak" have been used to describe a time-space grouping of a condition or disease. The United States' Centers for Disease Control and Prevention differentiates between these two terms in the following manner.

An outbreak or an epidemic exists when there are more cases of a particular disease than expected in a given area, or among a specific group of people, over a particular period of time. An aggregation of cases... regardless of whether the number of cases is more than expected, is a cluster [12].

Do our 15 cases of ulcerative colitis and Crohn's disease in Forest constitute a cluster or an outbreak? The reported incidence of pediatric Crohn's disease in industrialized countries is as high as 4.56 per 100,000 children per year [13]. In the 2000 census, Forest had a population of 8006, 2369 of whom were under 18 years of age. Three of our children with Crohn's disease who tested positive for MAP were 13 year old unrelated friends who played in each others' backyards and nearby creeks and developed symptoms of inflammatory bowel disease within seven months of each other. This represents an incidence rate of 217 cases per 100,000 children per year; more than 47 times the expected rate. We believe an incidence rate 47 times the expected rate qualifies this cluster as an outbreak.

In 2005, S.M.B. invited representatives from the Commonwealth of Virginia's Department of Health and the Centers for Disease Control and Prevention to review his cases of Crohn's disease from Forest and surrounding areas. While the investigators concluded that a cluster of Crohn's disease was present in Forest, no further steps were taken to determine the cause or causes of the cluster. From discussions with other physicians who care for people in Forest, we estimate an additional 45 individuals who live in Forest have been diagnosed with ulcerative colitis or Crohn's disease in the past 15 years. This appears to be an ongoing outbreak with our most recent case diagnosed in January 2011 that offers a unique opportunity to investigate possible etiologic factors involved in inflammatory bowel disease, and we encourage the Commonwealth of Virginia's Department of Health and the Centers for Disease Control and Prevention to reopen their investigation into this outbreak.

While MAP can be transmitted from an infected dairy cow to an uninfected calf across the placenta in-utero or via contaminated colostrum or milk after birth, the primary route of transmission in cattle is through the direct fecal-oral route [14]; the uninfected calf grazes on fields fertilized with MAP-contaminated manure, or suckles on manure coated teats. In contrast, transmission of MAP from dairy cow manure to humans appears to be indirect, and may occur when humans swallow or inhale MAPcontaminated water.

MAP is present [15] and may be concentrated in drinking water due to the organism's resistance to chlorination and its growth in biofilms and on metallic water pipes [16]. We postulate that in our outbreak, individuals inhaled aerosolized MAP from contaminated water in the river or creek tributaries near their homes. Other clusters of inflammatory bowel disease have occurred along rivers [6,7] and near lakes [7] that may have been contaminated with dairy cow feces.

MAP infection is endemic in dairy herds in the United States [17]. Although the prevalence of MAP infection in the dairy farms located in Forest is unknown, it is well documented that MAP is present and persists for years in the environment of almost three quarters of all dairy farms $[8,14,17]$.

Infected cows shed up to $1.6 \times 10^{7}$ organisms per 2 grams (0.07 ounces) of manure [14], a dose large enough to establish infection in a young calf, and excrete 12 to 15 gallons of such heavily contaminated 


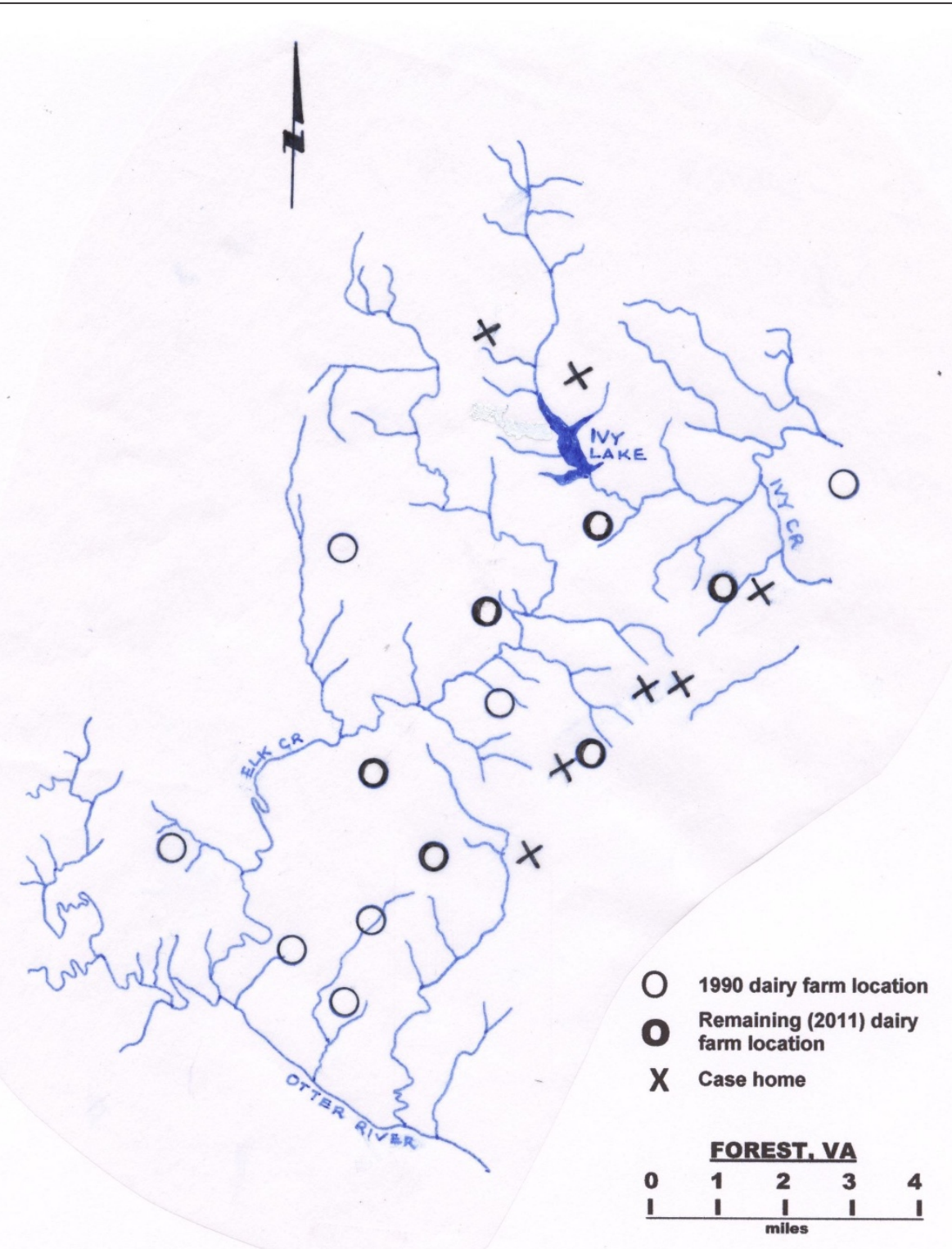

Figure 2 Map of seven of the 15 cases' homes from the 1994-2011 Forest, Virginia inflammatory bowel disease outbreak. Note that two case homes are immediately adjacent to dairy farms currently located in Forest, and the others are close to Otter River, Elk Creek or Ivy Creek tributaries.

manure per day. Liquid manure is usually collected in "lagoons" and then applied as fertilizer to agricultural land or spread onto the fields that dairy cows graze on $[8,14]$.

Rainfall can wash MAP-contaminated manure spread on fields or crops into nearby bodies of water. MAP has an extremely hydrophobic cell wall which causes the organism to adhere to and be concentrated on the surface of bodies of water. Bursting air bubbles can then aerosolize and further concentrate [18] the organism [8]. MAP can be concentrated 10,000 fold in the aerosolized water droplets that "are small enough to enter human alveoli." [16]

Inhalation is a common route of infection by $\mathrm{Myco-}$ bacterium avium complex organisms (of which MAP is a subspecies) [8], which cause gastrointestinal as well as respiratory diseases [19].

Nine of our eleven children with Crohn's disease were young males at the time of their diagnosis, in distinction to previous literature suggesting boys are perhaps twice more likely than girls to develop Crohn's disease [13]. The marked male predominance in our patients may 
reflect the fact that boys are more likely to play in creeks and streams than girls, but it may also be due to immunological differences between boys and girls putting boys at risk for particular infectious illnesses [20].

Other immunologic differences in our patients could put them at risk for inflammatory bowel disease including polymorphisms of the NOD-2 gene which codes for an intracellular pattern recognition molecule that is part of the innate immune response to intracellular pathogens including organisms of the genus Mycobacterium such as MAP [21,22]. Polymorphisms of NOD-2 are associated with Johne's disease in dairy cattle [23]. Loss of function mutations of the NOD-2 gene have been identified in approximately $15 \%$ of people affected with Crohn's disease [24] and NOD-2 deficient mice have impaired resistance to mycobacterial infections [25].

This case series adds to the circumstantial evidence that MAP may cause or at least initiate some cases of ulcerative colitis and Crohn's disease. The primary route of transmission of MAP from dairy cattle feces to humans is likely contaminated water.

\begin{abstract}
Acknowledgements
We are indebted to the seven young people and their parents who gave written permission for their homes to be depicted in Figure 2, and in particular to the case's mother who alerted us to the existence of this outbreak. We are also most grateful for the assistance of Dr. Michael Collins of the University of Wisconsin at Madison for information about dairy manure and its management, Dr. Ralph Frerichs of the University of California at Los Angeles for permission to use the original Broad Street pump map from his John Snow website as Figure 1, Craig Petersen of Nutrishare, Dr. Joseph Falkinham of Virginia Polytechnic Institute and State University and Dr. Marcel Behr of McGill University for helpful suggestions and reviews of early manuscript drafts, Carolyn Albright for the title, and Dr. Dodie Ruzicki and the librarians of Providence Sacred Heart Medical Center \& Children's Hospital's Health Sciences Library in Spokane, Washington for the references.
\end{abstract}

\section{Author details}

'13212 East Blossey Avenue, Spokane Valley, Washington, 99216 USA ${ }^{2}$ Division of Pediatric Gastroenterology, Hepatology and Nutrition, University of Virginia Children's Hospital, Box 800386 HSC, Charlottesville, Virginia 22908 USA. ${ }^{3}$ Department of Molecular Biology and Microbiology, Burnett School of Biomedical Sciences, BMS Building, Room 221, University of Central Florida College of Medicine, 4000 Central Florida Boulevard, Orlando, Florida, 32816 USA.

\section{Authors' contributions}

ESP was contacted by the parents of the seven young people whose homes are depicted in Figure 2 and wrote a first draft of the manuscript. SAN edited the manuscript and performed serum MAP testing on the nine children reported in the manuscript. SMB provided information on the additional children we discuss in the findings and extensively co-edited the manuscript. All authors have read and approved the final manuscript.

\section{Competing interests}

The authors declare that they have no competing interests. The authors received no funding for this case report.

Received: 7 December 2011 Accepted: 23 December 2011 Published: 23 December 2011

\section{References}

1. Mapping the 1854 Broad Street Pump Outbreak. [http://www.ph.ucla edu/epi/snow/mapsbroadstreet.html].

2. Uzoigwe JC, Khaitsa ML, Gibbs PS: Epidemiological evidence for Mycobacterium avium subspecies paratuberculosis as a cause of Crohn's disease. Epidemiol Infect 2007, 135:1057-1068.

3. Van Kruiningen HJ, Colombel JF, Cartun RW, Whitlock RH, Koopmans M, Kangro HO, Hoogkamp-Korstanje JA, Lecomte-Houcke M, Devred M, Paris JC, Cortot A: An in-depth study of Crohn's disease in two French families. Gastroenterology 1993, 104:351-360.

4. Van Kruiningen $H J$, Joossens M, Vermeire $S$, Joossens $S$, Debeugny $S$, Gower-Rousseau C, Cortot A, Colombel JF, Rutgeerts P, Vlietinck R: Environmental factors in familial Crohn's disease in Belgium. Inflammatory bowel diseases 2005, 11:360-365.

5. Van Kruiningen HJ, Joossens M, Colombel JF: Cluster of Crohn's disease in Herny, France, including 2 cases from a common residence. Inflammatory bowel diseases 2007, 13:1454-1455.

6. Pickup RW, Rhodes G, Arnott S, Sidi-Boumedine K, Bull TJ, Weightman A, Hurley M, Hermon-Taylor J: Mycobacterium avium subsp. paratuberculosis in the catchment area and water of the River Taff in South Wales, United Kingdom, and its potential relationship to clustering of Crohn's disease cases in the city of Cardiff. Applied and environmental microbiology 2005, 71:2130-2139.

7. Van Kruiningen HJ, Freda BJ: A clustering of Crohn's disease in Mankato, Minnesota. Inflamm Bowel Dis 2001, 7:27-33.

8. Hermon-Taylor J, Bull TJ, Sheridan JM, Cheng J, Stellakis ML, Sumar N: Causation of Crohn's disease by Mycobacterium avium subspecies paratuberculosis. Can J Gastroenterol 2000, 14:521-539.

9. Pierce ES: Ulcerative colitis and Crohn's disease: is Mycobacterium avium subspecies paratuberculosis the common villain? Gut pathogens 2010, $2: 21$.

10. Jones PH, Farver TB, Beaman B, Cetinkaya B, Morgan KL: Crohn's disease in people exposed to clinical cases of bovine paratuberculosis. Epidemiol Infect 2006, 134:49-56.

11. Naser SA, Hulten K, Shafran I, Graham DY, El-Zaatari FA: Specific seroreactivity of Crohn's disease patients against p35 and p36 antigens of M. avium subsp. paratuberculosis. Vet Microbiol 2000, 77:497-504.

12. What is an outbreak?. [http://www.cdc.gov/excite/classroom/outbreak/ objectives.htm\#what].

13. Kugathasan S, Judd RH, Hoffmann RG, Heikenen J, Telega G, Khan F, Weisdorf-Schindele S, San Pablo W, Perrault J, Park R, Yaffe M, Brown C, Rivera-Bennett MT, Halabi I, Martinez A, Blank E, Werlin SL, Rudolph CD, Binion DG, Alliance WPIBD: Epidemiologic and clinical characteristics of children with newly diagnosed inflammatory bowel disease in Wisconsin: a statewide population-based study. J Pediatr 2003, 143:525-531.

14. McKenna SL, Keefe GP, Tiwari A, VanLeeuwen J, Barkema HW: Johne's disease in Canada part II: disease impacts, risk factors, and control programs for dairy producers. Can Vet J 2006, 47:1089-1099.

15. Beumer A, King D, Donohue M, Mistry J, Covert T, Pfaller S: Detection of Mycobacterium avium subsp. paratuberculosis in drinking water and biofilms by quantitative PCR. Applied and environmental microbiology 2010, 76:7367-7370.

16. Falkinham JO: Surrounded by mycobacteria: nontuberculous mycobacteria in the human environment. J Appl Microbiol 2009, 107:356-367.

17. Lombard JE, Wagner BA, Smith RL, McCluskey BJ, Harris BN, Payeur JB, Garry FB, Salman MD: Evaluation of environmental sampling and culture to determine Mycobacterium avium subspecies paratuberculosis distribution and herd infection status on US dairy operations. J Dairy Sci 2006, 89:4163-4171.

18. Blanchard DC, Syzdek LD: Water-to-Air Transfer and Enrichment of Bacteria in Drops from Bursting Bubbles. Applied and environmental microbiology 1982, 43:1001-1005.

19. Primm TP, Lucero CA, Falkinham JO: Health impacts of environmental mycobacteria. Clinical microbiology reviews 2004, 17:98-106.

20. Libert $C$, Dejager $L$, Pinheiro I: The $\times$ chromosome in immune functions: when a chromosome makes the difference. Nat Rev Immunol 2010, 10:594-604. 
21. Ferwerda G, Kullberg BJ, de Jong DJ, Girardin SE, Langenberg DM, van Crevel R, Ottenhoff TH, Van der Meer JW, Netea MG: Mycobacterium paratuberculosis is recognized by Toll-like receptors and NOD2. I Leukoc Biol 2007, 82:1011-1018.

22. Coulombe F, Divangahi $M$, Veyrier F, de Leseleuc $L$, Gleason JL, Yang $Y$, Kelliher MA, Pandey AK, Sassetti CM, Reed MB, Behr MA: Increased NOD2mediated recognition of N-glycolyl muramyl dipeptide. J Exp Med 2009, 206:1709-1716.

23. Pinedo PJ, Buergelt CD, Donovan GA, Melendez P, Morel L, Wu R, Langaee TY, Rae DO: Association between CARD15/NOD2 gene polymorphisms and paratuberculosis infection in cattle. Vet Microbiol 2009, 134:346-352.

24. de Mesquita MB, Civitelli F, Levine A: Epidemiology, genes and inflammatory bowel diseases in childhood. Dig Liver Dis 2008, 40:3-11.

25. Divangahi M, Mostowy S, Coulombe F, Kozak R, Guillot L, Veyrier F, Kobayashi KS, Flavell RA, Gros P, Behr MA: NOD2-deficient mice have impaired resistance to Mycobacterium tuberculosis infection through defective innate and adaptive immunity. J Immunol 2008, 181:7157-7165.

doi:10.1186/1757-4749-3-20

Cite this article as: Pierce et al.: The Broad Street pump revisited: dairy farms and an ongoing outbreak of inflammatory bowel disease in Forest, Virginia. Gut Pathogens 2011 3:20.

\section{Submit your next manuscript to BioMed Central} and take full advantage of:

- Convenient online submission

- Thorough peer review

- No space constraints or color figure charges

- Immediate publication on acceptance

- Inclusion in PubMed, CAS, Scopus and Google Scholar

- Research which is freely available for redistribution

Submit your manuscript at www.biomedcentral.com/submit 